\title{
An Eco-friendly Approach for the Management of Collar Rot of Brinjal Caused by Sclerotium rolfsii SACC.
}

\author{
Ruthy Tabing* and Shashi Tiwari
}

Department of Plant Pathology, Sam Higginbottom University of Agriculture Technology and Sciences, Naini, Allahabad-211007, (U.P.) India

*Corresponding author

\begin{tabular}{|l|}
\hline Ke y w o r d s \\
Sclerotium rolfsii, \\
Trichoderma \\
viride, \\
Pseudomonas, \\
Bacillus, Cow \\
urine, Mustard \\
cake, Brinjal, Collar \\
rot
\end{tabular}

\section{Introduction}

Brinjal (Solanum melongena. L) is one of the important commercial vegetable crops grown in all parts of India and adapted to a wide range of climatic conditions. It is planted in three seasons, first in Kharif (June-Sep), second in Rabi (Nov-Feb) and third in the month of March. The solanaceous vegetable crop is covering an area of 704.96 ha with a total production of $12,994.77$ tonnes and productivity of 18.43 tonnes/ha. The leading brinjal producing countries in the order of importance are China, India, Japan, Italy and Spain. In India the major brinjal producing states in India are Andhra Pradesh, Maharashtra, Karnataka, Orissa, Madhya Pradesh and West Bengal. The fruit yield is about $16413 \mathrm{~kg} / \mathrm{ha}$ and $200000 \mathrm{~kg} / \mathrm{ha}$ in India and Andhra Pradesh, respectively. The fruits 
contain approximately, 92.0 per cent protein, 0.3 per cent fats and some minerals. Dark purple brinjal has more vitamin $\mathrm{C}$ than those with white skin. Bitterness in brinjal is due to presence of glycoalkaloids. It is highly productive and usually finds its place as the poor man's crop. The green leaves are the main source of the supply of anti-scorbic vitamin-C and an excellent_remedy for people suffering from liver complaints and diabetics (Chala, 1993).

More than ten diseases have been reported on brinjal from India (Rangaswami, 1972). The total cultivated area is about 530.30 ha, with productivity of $8703.80 \mathrm{t}$ in India. The total cultivated area in Uttar Pradesh is about 3.13 ha with productivity of about $33.98 \mathrm{t}$. The fruit yield is about $16413 \mathrm{~kg} / \mathrm{ha}$ and in India (CMIE, 2007). The pathogen $S$. rolfsii has been reported to inflict the fruit yield losses up to 90-100\% (Haque et al., 2001; Jadon, 2009). Among the soil borne fungal diseases, collar rot caused by Sclerotium rolfsii Sacc has become one of the constraints resulting in yield losses upto 16-30 per cent (Singh and Dhancholia, 1991). The affected plant shows invasion of the fungus, in the form of a girdle in the collar region, just above the soil line. The girdling progresses upwards, along with the white mycelium. Later on cream to chocolate coloured sclerotia will be formed. Wilting occurs within 3-5 days and the entire plant dries up with the abolition of the green canopy. The dried leaves remain intact with the stem with poor root growth.

S. rolfsii is a soil borne facultative pathogen, belongs to the sub-division Deuteromycotina, which has wide host range of more than 500 species of cultivated and wild plants in tropical and sub tropical regions (Aycock 1966). The pathogen is polyphagous non target fungus attacking many crops in India (Prasad et al., 1988) and throughout the world. The sclerotia can survive in the soil from a few months to several years. After germination, $S$. rolfsii hyphae produce oxalic acid and pectinolytic and cellulolytic enzymes which kill and disintegrate host tissues, starting a new infection (Le. 2011).

\section{Materials and Methods}

\section{Preparation of media}

\section{PDA: for Trichoderma viride and Sclerotium rolfsii}

The potatoes were peeled and cut into small pieces and boiled in $500 \mathrm{ml}$ of distilled water till they become soft. The extract obtained was filtered through muslin cloth and all the liquid was squeezed in beaker. $20 \mathrm{~g}$ of Agar was added bit by bit to the rest of $500 \mathrm{ml}$. Hot water to dissolve. Then $20 \mathrm{~g}$ of dextrose was added. Volume of broth was made up to 1000 $\mathrm{ml}$ by adding more distilled water. Then 200 $\mathrm{ml}$ of this solution was dispensed to each of five conical flasks and sterilized at $121^{\circ} \mathrm{C}$ at 15 lbs pressure /square inch for 15 minutes in an autoclave.

\section{Nutrient agar: for Bacillus subtillis}

\section{King's B media: for Pseudomonas fluorescens}

\section{Isolation and purification of pathogen}

The pathogen Sclerotium rolfsii was isolated from the infected brinjal plants showing typical symptoms of the disease. The part of collar or stem region showing typical symptoms of the disease was cut into small pieces. These pieces were surface sterilized with $0.1 \%$ mercuric chloride solution for 30 seconds. These were then washed thoroughly in sterile water thrice to remove traces of mercuric chloride and then transferred aseptically to sterilized potato dextrose agar (PDA) plates. They were incubated at $27 \pm 1^{\circ} \mathrm{C}$ 
and checked on 24 hour basis for the growth of the fungus. Later, the bit of fungal growth was transferred to PDA slants. The pure culture of the fungus was obtained by further growing the culture and following hyphal tip culture under aseptic conditions (Rangaswamy, 1972).

\section{Identification of pathogen}

For identification of the pathogen was confirmed by observing the morphological features of colony and spore characteristics.

\section{Maintenance of Sclerotium rolfsii}

After obtaining the pure culture of Sclerotium rolfsii, the pathogen was transferred to agar slants of containing potato dextrose agar medium. After growing the culture of Sclerotium rolfsii the slants were kept at low temperature in refrigerator. After every 20-25 days the pathogen was transferred to fresh slants for maintenance of pathogen culture.

\section{Mass multiplication}

Mass cultures of Sclerotium rolfsii were prepared using wheat grains in $1000 \mathrm{ml}$ conical flasks. wheat grains were soaked overnight in two per cent sucrose solution and air dry the remaining excess moisture then autoclaved, to which five discs $(5 \mathrm{~mm}$ diameter) from three days old culture of test pathogen was added and thoroughly shaken. These inoculated conical flasks were incubated for 2 weeks at $28 \pm 2^{\circ} \mathrm{C}$. The inoculated flasks were shaken periodically to allow the uniform growth and maximum utilization of substrate by the pathogen (Fig. 2).

\section{Incubation of pathogen}

The mass culture of $S$. rolfsii multiplied on wheat grains be directly incubated in the soil @ $100 \mathrm{~g} / \mathrm{m}^{2}$ of plot two weeks before transplanting. The inoculation was done in all the plots with 3 replications. The mass culture well mixed with the soil. The pathogen $S$. rolfsii inoculated in seed bed soil was allowed to multiply with proper soil moisture.

\section{Soil treatment}

The seven treatments (Bio control-agents) Trichoderma viride @ $2 \mathrm{~g}$ per plot. Pseudomonas flourescens @ 2g per plot. Bacillus subtilis @ 2g per plot (Patil et al., 2004) and (Botanicals) neem oil @ 5\% concentration per plot, eucalyptus oil @ 5\% concentration per plot, (Ramazeni et al., 2002) mustard cake @ 200g per plot and Cow urine @ 5\% per plot (Jandaik et al., 2015) were applied in the soil at $6-7 \mathrm{~cm}$ depth after one to two week of pathogen inoculation. The untreated plots will be left as control plot.

\section{Seedling root dip treatment}

The seedling roots were dipped into different treatments, Trichoderma viride @ 100g per liter.Pseudomonas fluorescens @ 100g per liter. Bacillus subtillis @ 100g per liter. (Patil et al, 2004) Neem oil @ 50ml $/ 1000 \mathrm{ml}$ of water. Eucalyptus oil @ 50ml/1000ml of water. Mustard cake @ 50ml/1000ml of water. Cow urine @ 50ml/1000ml of water, (Jandaik et al., 2015) for 30 seconds and dried in shade for 15-20mins Prior to planting.

\section{Results and Discussion}

\section{Pathogenicity test}

Pathogenicity test was conducted for testing the infectivity of $S$. rolfsii isolated from infected plant on brinjal by artificial inoculation of the test fungus. The first symptoms appeared after 15 days of inoculation. Affected seedlings develop severe rot and become wilted and could easily be pulled out. The part of collar or stem region showing typical symptoms of the disease 
were taken for re-isolation of the pathogen (Fig. 1). Then this re-isolated culture of pathogen compared with the original isolated culture. On comparison, re-isolated culture of pathogen was found to be identical with the previously isolated culture of pathogen, which confirms the Koch' postulates and pathogenic ability of isolated pathogen.

\section{In vitro evaluation of different treatments} against radial mycelium growth of Sclerotium rolfsii

Efficacy of different treatments on the radial mycelium growth of Sclerotium rolfsii is shown in (Table 1). Bio-agent and botanicals have profound effects on reduction of radial mycelium growth of the fungus. All the tested treatments significantly reduced radial mycelium growth of the fungus. Radial mycelium growth for all the tested treatments ranged from 0.0 to $9.0 \mathrm{~cm}$ recorded 5 days after inoculation. It was found that cow urine has significant effect in inhibiting the radial mycelium growth of Sclerotium rolfsii. Radial mycelium growth was not observed in cow urine $(0.0 \mathrm{~cm})$. Therefore cow urine has the highest inhibition percentage of $(100 \%)$. The lowest radial mycelium growth $(0.67,1.31$, 1.67 and $2.20 \mathrm{~cm}$ ) of Sclerotium rolfsii was recorded in case of Trichoderma viride at 2 day, 3 days, 4 days and 5 days after inoculation. Then followed by eucalyptus oil (0.52, 1.07, 2.05, and $3.87 \mathrm{~cm})$, Bacillus subtillis (1.45, 1.87, 2.05 and $4.27 \mathrm{~cm}$ ), Pseudomonas flourescens (2.20, 2.72, 3.33 and $4.37 \mathrm{~cm})$, neem oil $(1.08,4.90,7.32$ and $8.32 \mathrm{~cm})$ and mustard cake $(2.35,6.42,8.48$ and $8.68 \mathrm{~cm})$. The highest radial growth is observed in untreated Control $(9.0 \mathrm{~cm}$ ) (Fig. $3-7)$.

\section{Evaluation of different treatments on plant disease incidence under field condition}

The data recorded on plant disease incidence of collar rot of brinjal was done on 30, 60 and 90 days after transplantation. It was observed that plant disease incidence was significantly reduced in treated plots compared to untreated control plots (Table 2).

The lowest plant disease incidence (3.70, 7.41, 7.41) was recorded in Trichoderma. followed by Pseudomonas $(7.41,7.41,11.11)$ of disease incidence, Bacillus (11.11, 14.81, 14.81) of disease incidence, cow urine (14.81, $14.81,22.22)$ of disease incidence, neem oil (14.81, 22.22, 25.92) of disease incidence, eucalyptus oil $(14.81,25.92,29.63)$ of disease incidence, mustard cake $(29.63,33.33,40.74)$ of disease incidence were observed and the highest plant disease incidence $(33.33,44.44$, 55.56) was observed in control plot (Fig. 8).

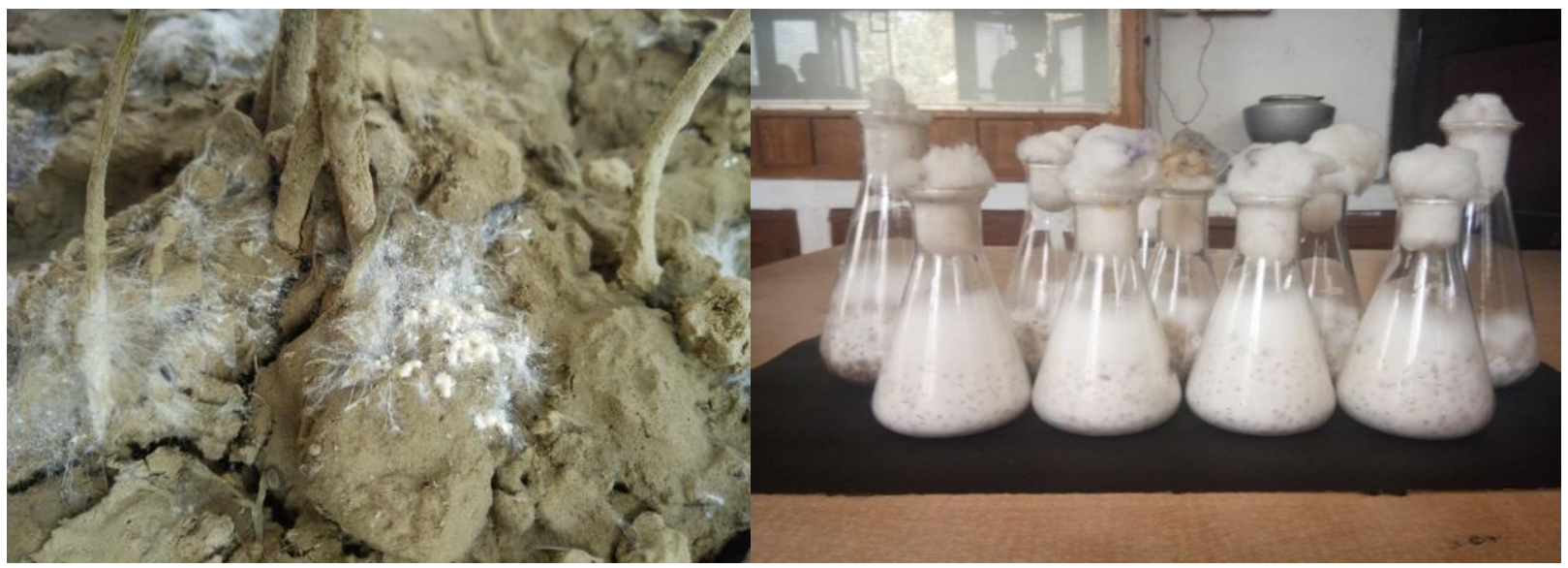

Fig.1 Formation of sclerotia around collar region of

Fig.2 Mass multiplication of Sclerotium rolfsii on brinjal wheat grains 


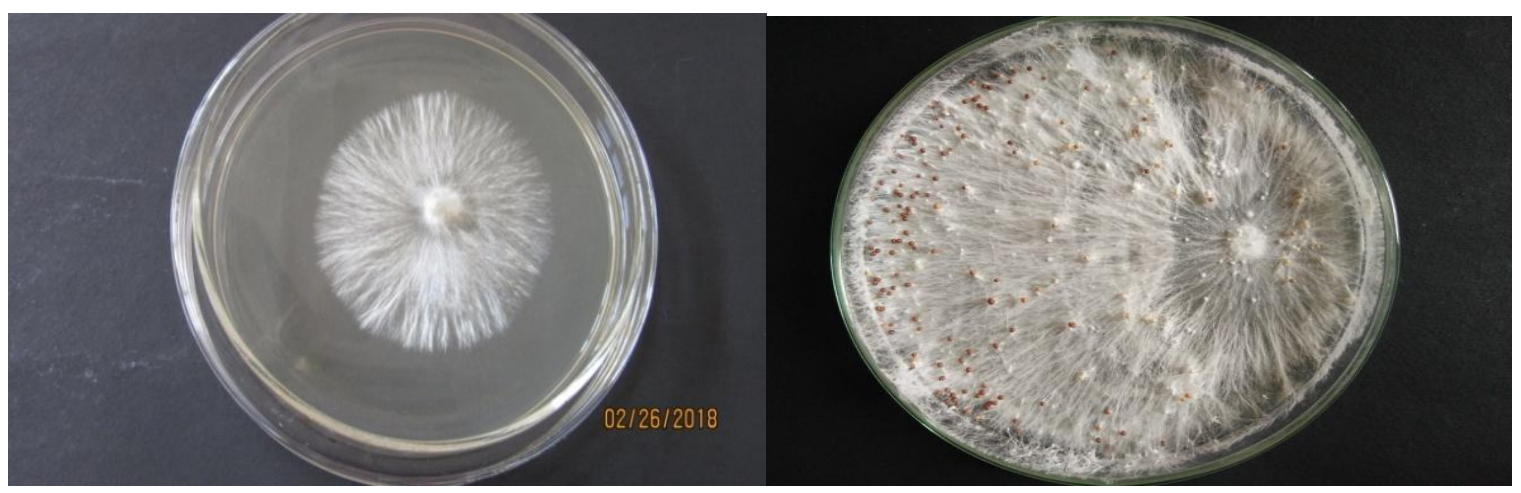

Fig.3 Mycelial growth of Sclorotium rolfsii on $3^{\text {rd }}$ day

Fig.4 Sclerotia formation on 30 days after inoculation

Fig.5 In vitro evaluation of different botanicals on mycelia growth of $S$. rolfsii

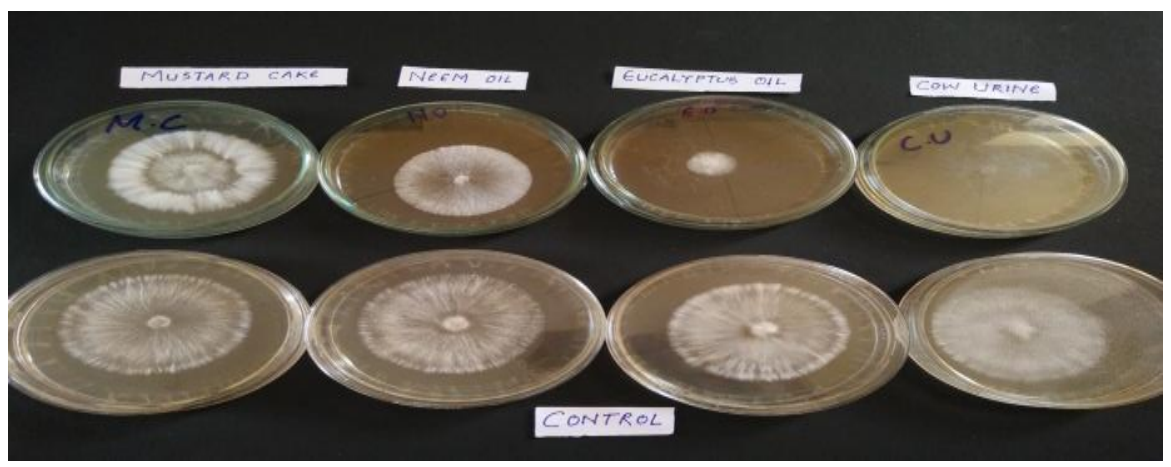

Fig.6 In vitro evaluation of different bio-agents on mycelium growth of $S$. rolfsii
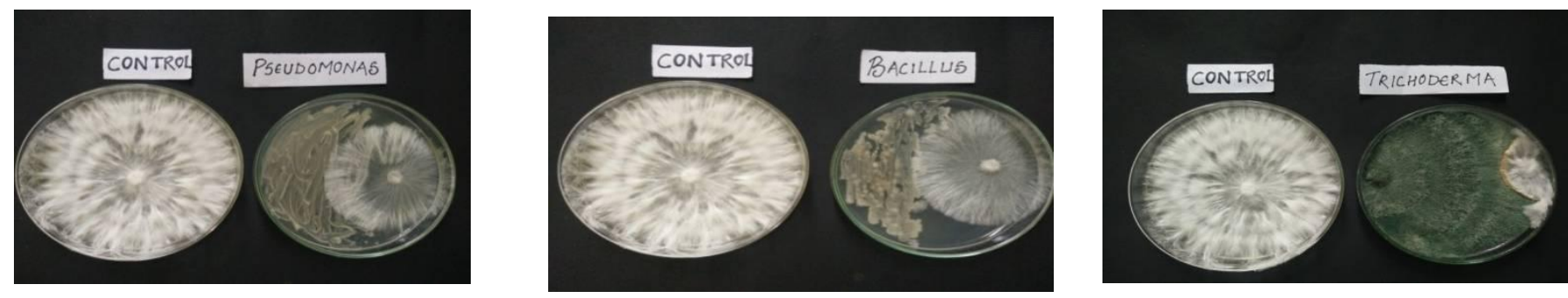

Fig.7 In vitro evaluation of different treatments on the mycelial growth of $S$. rolfsii was recorded on 48, 72, 96 and 120 hours after inoculation (HAI)

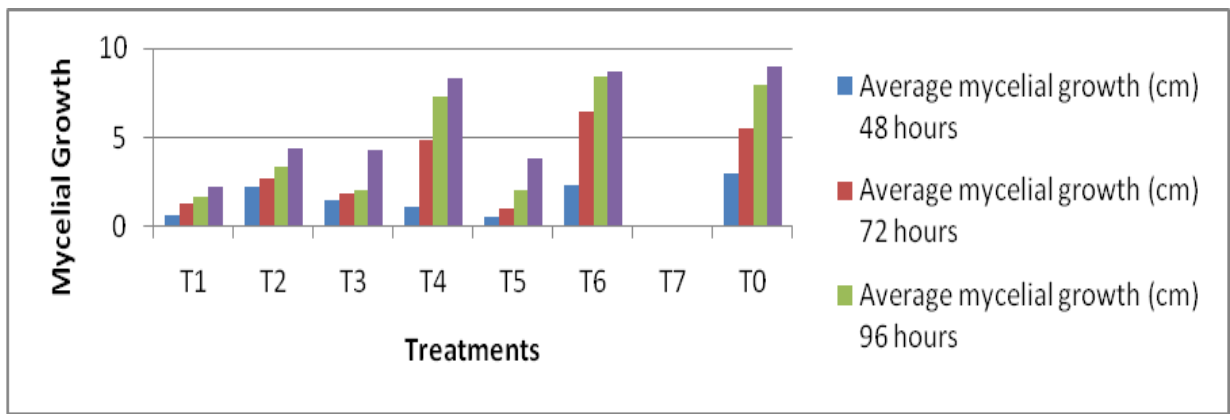


Fig.8 Evaluation of different treatments on plant disease incidence under field condition

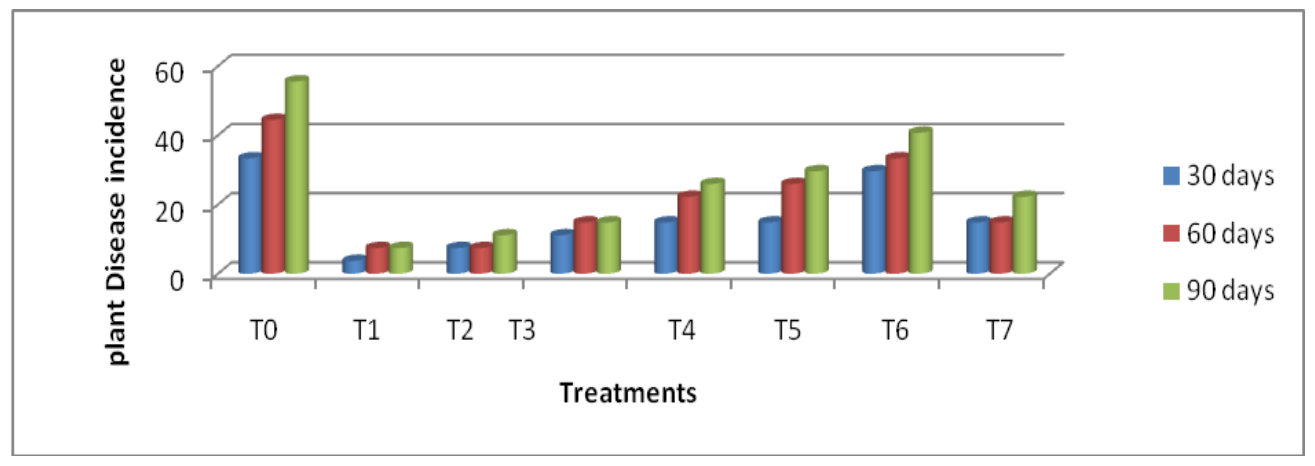

Table.1 In vitro evaluation of different treatments on the mycelial growth of $S$. rolfsii was recorded on 48, 72, 96 and 120 hours after inoculation (HAI)

\begin{tabular}{|c|c|c|c|c|c|}
\hline \multirow[t]{2}{*}{ Treatment } & \multicolumn{4}{|c|}{ Average mycelial growth $(\mathrm{cm})$} & \multirow[t]{2}{*}{ Inhibition \% } \\
\hline & 48 hours & 72 hours & 96 hours & 120 hours & \\
\hline $\mathbf{T}_{0}$-control & 2.97 & 5.52 & 7.98 & 8.97 & --- \\
\hline $\mathrm{T}_{1-}$ Trichoderma viride & 0.67 & 1.32 & 1.67 & 2.20 & 72.08 \\
\hline $\begin{array}{l}\mathrm{T}_{2} \text {-Pseudomonas } \\
\text { fluorescens }\end{array}$ & 2.20 & 2.72 & 3.33 & 4.37 & 44.67 \\
\hline $\mathbf{T}_{3}$-Bacillus subtillis & 1.45 & 1.87 & 2.05 & 4.27 & 45.93 \\
\hline $\mathbf{T}_{4}$-Neem oil & 1.08 & 4.90 & 7.32 & 8.32 & 7.66 \\
\hline$T_{5}$-Eucalyptus oil & 0.52 & 1.07 & 2.05 & 3.87 & 57.11 \\
\hline $\mathbf{T}_{6}$-Mustard cake & 2.35 & 6.42 & 8.45 & 8.68 & 3.55 \\
\hline $\mathbf{T}_{7}$-Cowurine & 0.00 & 0.00 & 0.00 & 0.00 & 100 \\
\hline S. Em & 0.172 & 0.343 & 0.569 & 0.622 & \\
\hline CD (5\%) & 0.516 & 1.027 & 1.705 & 1.864 & \\
\hline
\end{tabular}

Table.2 Evaluation of different treatments on plant disease incidence under field condition

\begin{tabular}{|l|c|c|c|}
\hline \multicolumn{3}{|c|}{ Plant Disease Incidence } \\
\hline Treatments & $\mathbf{3 0}$ days & $\mathbf{6 0}$ days & $\mathbf{9 0}$ days \\
\hline $\mathbf{T}_{\mathbf{0}}$-control & 33.33 & 44.44 & 55.56 \\
\hline $\mathbf{T}_{\mathbf{1}}$-Trichoderma viride & 3.70 & 7.41 & 7.41 \\
\hline $\begin{array}{l}\mathbf{T}_{\mathbf{2}} \text {-Pseudomonas } \\
\text { fluorescens }\end{array}$ & 7.41 & 7.41 & 11.11 \\
\hline $\mathbf{T}_{\mathbf{3}}$-Bacillus subtillis & 11.11 & 14.81 & 14.81 \\
\hline $\mathbf{T}_{\mathbf{4}}$-Neem oil & 14.81 & 22.22 & 25.92 \\
\hline $\mathbf{T}_{\mathbf{5}}$-Eucalyptus oil & 14.81 & 25.92 & 29.63 \\
\hline $\mathbf{T}_{\mathbf{6}}$-Mustard cake & 29.63 & 33.33 & 40.74 \\
\hline $\mathbf{T}_{\mathbf{7}}$-Cowurine & 14.81 & 14.81 & 22.22 \\
\hline \multicolumn{1}{|c|}{ S.Em } & 4.84 & 6.99 & 7.82 \\
\hline CD (5\%) & 10.92 & 19.63 & 23.25 \\
\hline
\end{tabular}


Different treatments have different effect on the mycelium growth. Minimum radial mycelium growth was observed in Trichoderma viride $(2.2 \mathrm{~cm})$ and cow urine (0.00). The above findings confirm the findings of Patil and Raut (2008) reported that the Trichoderma viride inhibited the mycelial growth of Sclerotium rolfsii.

Basak and Lee (2005) studied the efficacy and in vitro activities of cow urine and dung for controlling wilt caused by $F$. oxysporum f.sp. cucumerinum of cucumber. Cow urine showed 100 per cent inhibition of wilt pathogen. Joseph and sankarganesh (2011) studied the antifungal activity of panchagavya and cow urine against soil borne pathogen.

It was observed that plant disease incidence was significantly reduced in treated plots compared to untreated control plots. The lowest plant disease incidence (3.70, 7.41, 7.41) was recorded in Trichoderma. Franken et al., (2002) observed that Trichoderma spp. Colonize plant roots prior to stimulation of plant growth and provide protection against invasion of infectious foreign organisms.

The summary and conclusion of the study are as follows:

Among all the treatments, cow urine was significantly effective in inhibiting the mycelium growth $(0.0 \mathrm{~cm})$, with highest disease inhibition percentage (100\%). Trichoderma viride was found to be effective in reducing the growth of mycelium $(2.2 \mathrm{~cm})$, with disease inhibition percentage of (77.81\%). The highest mycelium growth was observed in control plate $(9 \mathrm{~cm})$.

Under field condition, the disease incidence of collar rot of brinjal was recorded in 30, 60 and 90 DAT. The highest disease incidence (33.33, 44.44 and 55.56) was recorded in control plot. Followed by Mustard cake
(29.63, 33.33 and 40.74). The lowest disease incidence (3.70, 7.41 and 7.41) was recorded in plots treated with Trichoderma viride.

It can be concluded from the above findings that, since the fungus Sclerotium rolfsii is a soil borne pathogen, soil treatments with bioagents and botanicals have significant effect in controlling the collar rot in brinjal. Trichoderma viride has significant effect in reducing the plant disease incidence in field condition. Cow urine was found highly effective in inhibiting $(100 \%)$ of mycelium growth in lab condition. The root dip method application helps the plant to resist the pathogen attack after transplantation. Usage of chemical methods leads to environment, soil and water pollution. Continuous usage of chemical makes the pathogen gain resistant to it. Hence, it can be concluded that ecofriendly approach for the management of collar rot is more advisable in today's world.

\section{References}

Aycock, R. 1966. Stem rot and other diseases caused by Sclerotium rolfsii or the status of Rolf's fungus after 70 years. N.C. Agric. Exp. Stn. Tech. Bull. 174.

C. M. I. E. Agriculture.2007. Centre for Monitoring Indian Economy Pvt. Ltd. Andheri(East), Mumbai.

Chala, M. L. 1993.Improvement of brinjal. In Advances in Horticulture (ed.) by Chadha K L, Malhotra Publishing House, New Delhi pp. 105.

Fery, R. L. and Dukes, S. D. 2002. Southern blight (Sclerotium rolfsii Sacc.) of cowpea: yield-loss estimates and sources of resistance. Crop Protection.21: 403-408.

Franken, P.G., Khun and V. Gianianazzipearson. 2002. Development of molecular biology of arbuscular mycorrhizal fungi. pp. 325-348. Molecular biology of fungal 
development. (Ed): H.D. Osiewacz. Marcel dekker, New York.

Gupta, S.K., Sharma, A., Shyam, K.R. and Sharma, J.C. 2002. Role of soil temperature and moisture on the development of crown rot (Sclerotium rolfsii) of French bean. Plant Diseases Research. 17: 366-368.

Haque, M.M., Siddique, M.B., Meah, M.B. and Islam, M.N. 2001. Control of foot rot of brinjal through chemicals and organic soil amendments. Journal of Biological Sciences. I:946-948.

Jandaik, S., Thakur, P. and Kumar, V. 2015.Efficacy of Cow Urine as Plant Growth Enhancer and Antifungal Agent. Advances in Agriculture Volume 2015, Article ID 620368.

Le, C.N. 2011. Diversity and biological control of Sclerotium rolfsii, causal agent of stem rot of groundnut. 152pp.

Lewis, J. A. and Papavizas, G. C. 1991.Biocontrol of plant disease, the approach for tomorrow. Crop protection, 10: 95-105.

Patil, P.R., Raut B.T., Shinde V.B. and ingole M.N. 2004. Role of antagonists in inhibition of Rhizoctonia bataticola and sclerotium rolfsii causing seed/root/ stem rot of sunflower. Annals of plant Physiology 18 (2): 195-197.
Prasad, B. K., Thakur, S. P., Sinha, and Narayana, N. 1988. Influence of temperature on the soft rot of tomato fruit due to Sclerotium rolfsii. Indian Phytopathology, 44:256.

Ramezani, H., Singh, H.P., Batish, D.R., Kohli, R. K. and Dargan, J. S. 2002.Fungicidaleffect of volatile oils from Eucalyptus citriodora and its major constituent citronellal. New Zealand Plant Protection. 55, 57-62.

Rangaswami,G. 1972. Diseases of crop plants in India. Prentice hall of India Pvt. Ltd., New Delhi,520pp.

Singh, A. and Singh, H. B. 2004. Control of collar rot in mint (Mentha spp) caused by Sclerotium rolfsii using biological means. Current Science. 87 (3): 362366.

Singh, and Dhancholia, S. 1991. A noteworthy disease of brinjal caused by Sclerotium rolfsii Sacc. Himachal Pradesh Journal of Agricultural Research.17 (1\&2): 119-120.

Singh, M. and Shukla, T. N. 1984.Control of collar rot of brinjal caused by Sclerotium rolfsii. Indian Journal of Mycology and Plant Pathology 14 (5):81-83.

\section{How to cite this article:}

Ruthy Tabing and Shashi Tiwari. 2018. An Eco-friendly Approach for the Management of Collar Rot of Brinjal Caused by Sclerotium rolfsii SACC. Int.J.Curr.Microbiol.App.Sci. 7(12): 929-936. doi: https://doi.org/10.20546/ijcmas.2018.712.116 